\title{
Improving Children's Cognitive Intelligence Through Literacy Management
}

\author{
Umiarso $^{1}$, Hasan Baharun ${ }^{2}$, Zamroni $^{3}$, Fathor Rozi ${ }^{4}$, Nurul Hidayati ${ }^{5}$ \\ Pendidikan Agama Islam, Universitas Muhammadiyah Malang, Indonesia ${ }^{1}$, Manajemen \\ Pendidikan Islam, Universitas Nurul Jadid, Paiton, Probolinggo, Indonesia ${ }^{2}$, Manajemen \\ Pendidikan Islam, Universitas Islam Negeri Sultan Aji Muhammad Idris Samarinda, Indonesia ${ }^{3}$, \\ Pendidikan Agama Islam, Universitas Nurul Jadid, Paiton, Probolinggo, Indonesia ${ }^{4}$, Pendidikan \\ Islam Anak Usia Dini, Universitas Nurul Jadid, Paiton, Probolinggo, Indonesia ${ }^{5}$
}

DOI: $\underline{10.31004 / o b s e s i . v 6 i 3.1817}$

\begin{abstract}
Cognitive intelligence has a vital role in children's growth and development to solve remembering, logical thinking, and symbolic thinking activities. This study aim to explore how the implementation of in improving early childhood cognitive intelligence in RA Tania, Paiton, Probolinggo?. This research uses a qualitative case study approach. Researchers conducted observations and interviews with principals, teachers, students, and guardians of students. The data analysis technique is carried out in stages, including data presentation, data reduction, and concluding. The results showed that literacy management in improving early childhood cognitive intelligence was carried out through; identification of needs, implementation of literacy management, evaluation, and a tiered plan. This study implies that literacy management can increase interest in reading and writing and an understanding of simple problem-solving in early childhood.
\end{abstract}

Keyword: cognitive intelligence; literacy; management

\begin{abstract}
Abstrak
Kecerdasan kognitif memiliki peran yang sangat penting bagi tumbuh kembangnya anak agar dapat memecahkan masalah-masalah yang berkaitan dengan aktivitas mengingat, berpikir logis, dan berpikir simbolik. Penelitian ini bertujuan untuk mengeksplorasi tentang bagaimana implementasi manajemen literasi dalam meningkatkan kecerdasan kognitif anak usia dini di RA Tania, Paiton, Probolinggo ?. Penelitian ini menggunakan pendekatan kualitatif jenis studi kasus. Peneliti melakukan observasi dan interview terhadap kepala sekolah, guru, siswa dan wali murid. Teknik analisis datanya dilakukan secara bertahap, yang dimulai dari penyajian data, reduksi data dan penarikan kesimpulan. Hasil penelitian menunjukkan bahwa manajemen literasi dalam meningkatkan kecerdasan kognitif anak usia dini dilakukan melalui; identifikasi kebutuhan, implementasi manajemen literasi, evaluasi dan dilanjutkan dengan rencana berjenjang. Penelitian ini memberikan implikasi bahwa manajemen literasi mampu meningkatkan minat baca tulis, serta pemahaman tentang pemecahan masalah sederhana pada anakusia dini.
\end{abstract}

Kata Kunci: kecerdasan kognitif; literasi; manajemen

Copyright (c) 2021 Umiarso, et al.

$\triangle$ Corresponding author :

Email Address : ha54nbaharun@gmail.com (Paiton, Probolinggo, Jawa Timur, Indonesia)

Received 25 April 2021, Accepted 4 October 2021, Published 7 October 2021 


\section{INTRODUCTION}

Children in the age range 0-6 and 0-8 years are still in the category of early childhood. At this age, they are a unique group of children, both their growth and development processes (Nurjannah, 2017). The golden age or the golden age in early childhood is at 0-5 years. The research results indicate that; During the first four years of development that occurs as large as the next 14 years, the child's brain experiences a developmental freeze after that period. Therefore, this period is called the golden age because regardless of the capacity of intelligence, it will not increase after this period (Trenggonowati \& Kulsum, 2018).

Early Childhood Education has a vital role in subsequent child development(Alfina \& Anwar, 2020). This age is considered a golden period for children to stimulate and develop their potential (Suryaningrum et al., 2016; Nurmiyanti \& Candra, 2019). Early childhood education (ECE) is a collection of planned and structured activities for children aged birth to six years old (Ichsan \& Hutagalung, 2019). Children have characteristics that set them apart from adults. They are always full of energy, vitality, passion, and curiosity about what they hear, see, and feel, as though they are constantly exploring and learning. Education is a place where children's development is aided in six different ways, including cognitive development (Heliawati, 2019).

Cognitive development is linked to the quality of human life, and it is a stage of development that occurs swiftly between the ages of 24 and 72 months (Tatminingsih, 2019; Fardiah et al., 2019). The word "cognitive development" refers to the process of improving human thinking skills such as attention, memory, reasoning, creativity, and language. Fifty percent of a child's cognitive potential is established at the age of four and achieved at the age of eight, and by the age of eighteen, 80 percent of total intelligence has been accomplished (Rahayu et al., 2014).

Early childhood cognitive development includes; 1) Learning and problem-solving skills include the ability to solve minor problems in everyday life in a flexible and socially acceptable manner and the ability to apply information or experience in new situations (Anida \& Eliza, 2020); 2) Differences, classifications, patterns, taking the initiative, planning, and identifying cause and effect are all examples of logical reasoning (Rahmatika et al., 2019; Novitasari \& Fauziddin, 2020); and 3) The ability to recognize, mention, and use the concept of numbers, recognize letters, and describe various items and their imagination in the form of pictures are all examples of symbolic thinking. To achieve optimal child development, parental involvement and access to quality PAUD services are needed. In the cognitive development stage, early childhood 0-6 years old enters the sensorimotor and pre-operational stages (Nur et al., 2020).

The period of conception determines cognitive development, which is impacted by heredity or inheritance. However, to optimize development at the level of intelligence, environmental variables and the child's maturity in interacting with others play a role in developing this cognitive capacity (Arimbi et al., 2018). Family environmental elements strongly influence a child's development (Saefudin et al., 2019; Ngiode \& Erwinsyah, 2020; Arif \& Pratama, 2019). In the heart of the neurological system, this cognitive ability develops gradually in tandem with physical and neural development (Nasution et al., 2019a). Selecting and sorting shapes, types, sizes, numbers, and letters can reveal cognitive growth (Masyithoh, 2019).

The development of cognitive capacities is a crucial period in early childhood development, according to Made et al. (2018). This cognitive ability develops gradually in line with physical and neural growth at the heart of the neurological system (Nasution et al., 2019). The central human jumpy system is cognitive development (Fardiah et al., 2019).

The results of an initial field study conducted by researchers in June 2021 on learning activities carried out by teachers and students at Raudlatul Athfal (RA) Tania, Paiton, Probolinggo, it was found that; the level of recognition of letters and numbers is still minimal and cannot solve simple everyday problems. To develop the full potential of children, good 
handling is needed from various components, including from the teacher who designs the learning process and the environment. Environmental factors have the most significant influence in changing each child's behavior (Juniayanti et al., 2016). This means that the school environment is essential for educating and developing children's potential (Wahyono, 2019). Therefore, we need management to embrace and solve existing problems (Mahmud \& Suratman, 2019; Roviin, 2020; Tharaba, 2020; Musaddad, 2021) , especially regarding literacy needs to be appropriately managed to improve children's cognitive intelligence.

The results of the preliminary research, which are the basis of this research, are; Yarmi \& Wardhani (2020) in their research, said that Fun Garden of Literacy could effectively increase early childhood reading interest. According to Mardliyah et al., (2020), early literacy accelerates language development in early childhood by making storybooks. Nahdi \& Yunitasari (2019) said that the application of his handsome method to develop literacy skills. The most dominant early reading language for children is to fit into "developing according to expectations" criteria. Children aged 5-6 years, on the other hand, have little early reading skills that "begin to develop."

In their study, Afnida \& Suparno (2020) found that teacher literacy competence impacts the variety of activities created and helps encourage children's language abilities from a young age. Literacy is a feature of language development in early childhood education, according to Hewi (2020). Reading and writing are sometimes used interchangeably with the terms literacy and literacy. However, literacy encompasses more than just reading and writing. Children's literacy abilities, which they acquired at a young age, specifically between the ages of two and five years, have allowed them to demonstrate literacy swiftly (Inten \& Permatasari, 2019). At that age, children are at the level of early childhood education. The existence of early childhood education institutions (PAUD) becomes an inseparable need from the next level of education that must be passed by students (ZR \& Eliza, 2020).

Mukhtar \& Amalia (2019) said that the use of the concept of literacy is quite dynamic, and literacy skills are a continuum, starting from the ability to read, then read and write, continue to think critically, speak spoken language that is used for lifelong learning both at home and in the community. Furthermore, Basyiroh (2017) said that literacy development in children is closely related to language or communication skills. Communication is intended to fulfill the function of exchanging thoughts and feelings.

At least, in literacy activities, there are two crucial elements in communicating in early childhood. First, children must use forms of language that are meaningful to the people they are communicating with. Second, in speaking, children must understand the language used by others so that speaking skills affect children's social and personal adjustments (Mukhibat, 2020). Literacy or communication skills in children will affect their social, emotional, and cognitive development. If children can communicate with the surrounding environment, they will grow self-confidence and socialize or be accepted in their environment. This confirms that language skills affect a child's social and personal adjustment; of course, it will also affect his emotional and cognitive development (Nahdi \& Yunitasari, 2019).

Some of these studies show the importance of literacy management in developing children's cognitive intelligence so that they can solve problems related to thinking, remembering (Ritonga \& Sutapa, 2020; Fahmi et al., 2020), reasoning, planning, understanding, analyzing, synthesizing (Yuwono, 2020), and so on, particularly in Raudlatul Athfal (RA) Tania, Paiton, and Probolinggo.

Based on the above, the researcher is interested in combining two different concepts, namely the development of literacy and cognitive intelligence, in one research theme based on the importance of planned and systematic management implementation in achieving the desired learning objectives. This distinguishes this study from previous studies, where researchers used a managerial approach to succeed in school literacy activities in improving children's cognitive intelligence. This study aims to analyze and understand literacy 
DOI: $10.31004 /$ obsesi.v6i3.2022

management in enhancing children's cognitive intelligence conducted at Raudlatul Athfal (RA) Tania, Paiton, Probolinggo.

\section{METHODOLOGY}

This study employs a case study approach to qualitative research. Researchers are familiar with the literacy movement's application in schools. Qualitative research aims to understand the phenomena experienced by the study object, such as behavior, perception, motivation, action, and so on, holistically and descriptively in language and text in a specific natural setting using various natural methodologies.

The RA Tania Institute in Paiton, Probolinggo, was the site of this study. This study aims to describe literacy management in the context of enhancing children's cognitive intelligence.

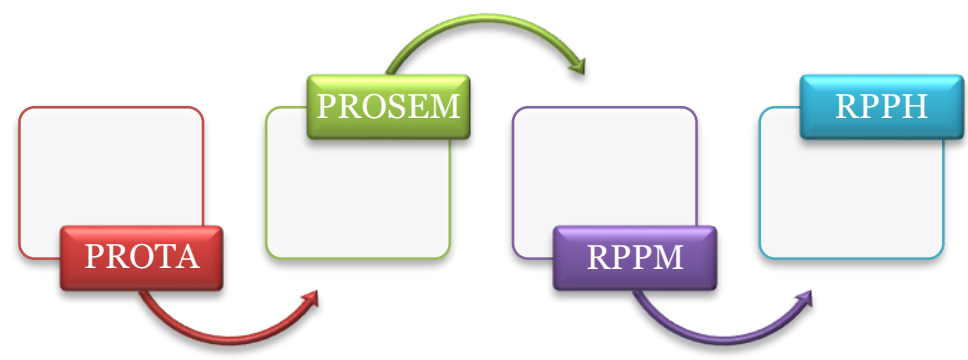

Figure 1: Learning Management Structure

In determining the informants, the researcher used a purposive sampling technique, where the researcher chose the informants according to their abilities and provided accurate information to the researchers about the themes being studied. There were five informants in the study consisting of; principals, teachers, parents, and students. Researchers conducted interviews with informants based on interview guidelines made previously, which were related to planning, implementation, evaluation techniques carried out by schools in improving children's intelligence. The researcher also observed the learning activities, such as keeping the reading corner in the classroom, looking at literacy posters, watching the library. Furthermore, the researcher documented some essential data related to the research theme.

The researcher then analyzes the data by referring to the concept of Milles and Huberman, which starts from collecting data as a whole from the results of interviews, observations, and documentation, then sorting and selecting data through data reduction activities. Next, the researcher presents the results of the study and concludes the findings of the study.

\section{RESULTS AND DISCUSSION}

The findings revealed that in Raudlatul Athfal (RA) Tania, Paiton, Probolinggo, literacy management was used to improve children's cognitive intelligence as follows; identification of needs, implementation of literacy management, evaluation, and a tiered plan.

\section{Identification of Children's Needs}

The needs analysis is likened to a description of the current condition (actual condition) and compared to the state; it should be accompanied by a recommendation of a solution model to overcome the gap between the situation that occurs and the conditions that should happen, especially in RA Tania. The following identifies the needs researchers found at the RA Tania institution in building literacy management at the institution, namely the introduction of reading and writing in children pleasantly without intimidation or coercion against students.

Shafiah, as the Head of RA Tania, said that the literacy implementation carried out at RA Tania prioritized the needs of students, namely programs for writing, reading, and daily creative problem solving; identifying these needs is one of the efforts to achieve excellent and 
appropriate education and learning programs. Target by taking the right approach to needs analysis. This effort will be able to increase the effectiveness of existing education programs.

As a teacher at the institution, Saleha emphasized that the required implementation of literacy management is regulated by a game system involving APE, storytelling, watching videos, and environmental science programs that are carried out at the end of the learning theme, namely the peak of the article. All literacy management learning processes have been contained in the school curriculum.

Rif'atin said practically conveying that the identification of needs carried out by teachers in literacy management to improve the cognitive intelligence of early childhood at RA Tania by introducing letters, recognizing numbers, recognizing colors, and naming animals/plants tools for needs. Daily activities and so on that have been included in the 13th curriculum made by the school.

Shafiah said she also revealed that cognitive development through literacy was carried out through the introduction of numbers, letters, colors, and problem-solving that had been stated in the annual program (PROTA) activity then (PROSEM) semester program continued (RPPM) weekly learning implementation plan and elaborated again in the form ( RPPH) daily learning implementation plan.

By identifying the various needs needed, the literacy management at RA Tania is more structured and leads to the goals to be achieved, making it easier to implement the control. That way, literacy management to increase cognitive intelligence is more effective and maximal.

Literacy Management Implementation Design

The implementation of literacy management is carried out in a fun way and then designed through game methods that attract children's interest in implementing literacy to improve cognitive intelligence in students, such as the following interview results:

Shafiah, as the head of RA Tania, said that literacy management at this institution was designed through an activity called the School Literacy Movement (GLS). This movement is carried out in various activities that support the achievement of the school literacy movement; the different implementation activities include; first, the activity of singing 15 minutes before the move; second, providing a reading corner in each class; third, the use of the library, fourth, the introduction of the scientific environment at the peak of the theme.

Rif'atin also said literacy implementation activities were carried out at the opening, core, and closing stages. The opening stage is 15 minutes before the core learning activities begin; students at RA Tania are given an introduction to the letters of the alphabet and numbers, which is done by singing and assisted with APE number cards, notes, and colors so that students are accustomed to recognizing the letters of the alphabet and numbers carried out by the teacher. . Then in the core activity, students are divided into three groups who will carry out three core activities; the first group, reading corner, activities in the reading corner children are introduced to simple words through APE and learn to write letters for group A through literacy books specially designed by the institution, while for group B understand to write simple words. The second group, telling or listening to stories and then coloring magazines, introduces children to colors, the social environment, and the natural environment. Group three, APE Literacy, has APE literacy goals that the institution has specially designed, such as APE blocks, arranging color blocks, number blocks, letter blocks set according to children's imagination, APE snake ladders, children playing snakes and ladders letters, numbers, fruit, other animals, and many other APEs that can stimulate children to be interested in the world of literacy in increasing cognitive intelligence. In the closing stage, the teacher repeats and remembers the learning and then conveys the learning activities on the next day. 


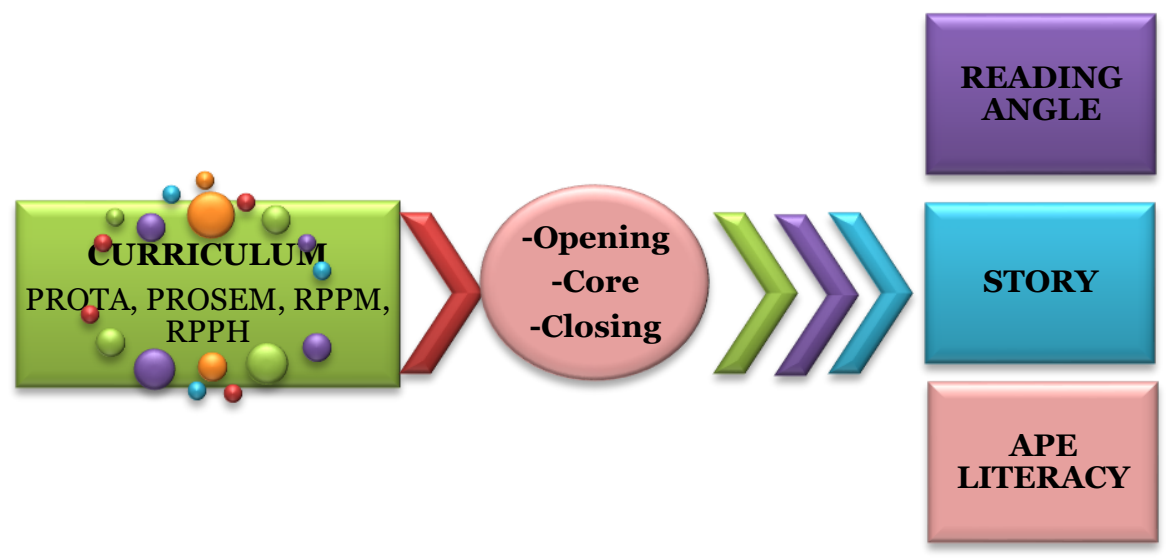

Figure 2: implementation of literacy management

In line with this statement, Saleha also said that the provision of reading corners carried out in each class at RA Tania improved children's literacy understanding, especially in the field of cognitive development. The application of the reading corner is carried out with the help of educational teaching aids (APE) such as number/word cards, letter cards, animal/plant identification cards, and so on. Reading comprehension can also be done by students during breaks by visiting the library at school. Still, in the implementation of the library at RA, Tania using the help of tutors or accompanying teachers to accompany students when entering the library room, so there is a particular time in visits to the library arranged by the homeroom teacher.

Shafiah also emphasized that listening to stories and fairy tales told directly by teachers and parents is the right entertainment for children. In addition to entertaining, this activity also has many benefits that can help children grow and develop in the future. Storytelling and storytelling have many benefits for children, such as; 1 ) enrich the child's vocabulary; 2) build emotional closeness between educators and children; 3 ) listening to stories and fairy tales can stimulate imagination and thinking so that children grow up to be creative children, practice listening skills; 4) after reading a fairy tale, continue by asking the child about the story or allowing him to retell the story, this is useful for training his memory; 5) the more children hear, the easier it is for children to speak; 6) when storytelling, laughing together and being spoiled, it can strengthen the relationship between children, a means of entertainment and attention-grabbing; 7) an effective medium for conveying messages/moral and religious values; 8) help the process of imitating the good deeds of the characters in the story and build a noble character, and 9) arouse interest in reading.

The implementation of storytelling or storytelling is also done by providing picture books and accompanying children in the reading process, such as identifying body parts and recognizing easily recognizable objects such as homes, markets, playgrounds, and several other things. Through storytelling, students will be easily stimulated to hone their cognitive intelligence, in addition to storytelling application is also in the form of an introduction to the natural surroundings, which is carried out every Saturday, by introducing the nature around students, they can reason, add insight and experience of students in understanding the environment. It can improve and develop children's cognitive abilities naturally.

APE literacy assistance is beneficial and makes it easier for teachers to implement learning because, through APE, children can be creative and imagine themselves. Children are increasingly challenged to solve problems creatively through the APE they use; APE also provokes children with more curiosity. More children ask the teacher about things that make them curious.

Cahya, one of the students, said that he listened to fairy tales from the teacher and then saw the pictures in the storybooks were entertaining. He also said that he could recognize colors, animals, and plants from the storybook. Qomariyah, one of RA Tania's guardians, said 
that with the School Literacy Movement (GLS), our children understand words more quickly, enjoy writing, and understand simple terms of reasoning. We also apply this school literacy movement at home with the methods taught by RA Tania's teacher; we also coordinate directly with teachers through communication books or liaison books to control our children's development. This literacy management implementation design can improve and develop students' cognitive intelligence with an attractive and not dull design to develop cognitive intelligence in a relaxed and fun way.

\section{Tiered Plan}

A tiered plan is carried out to make further plans to improve and strengthen literacy management that has been previously planned. This Han was carried out at RA Tania to support the success of the scheduled program.

Shafiah, said that the steps taken in the tiered plan are backup steps that can be taken when needed. The next plan is a mobile library that comes to school to provide exciting education for students so that students prefer the world of literacy. This plan intends to identify all the conveniences and obstacles; this needs to be placed to measure the organization's ability to achieve goals. Therefore, it is necessary to know the internal and external environmental factors that can help the organization achieve its goals or cause problems. Although difficult to do, anticipating circumstances, issues, and opportunities, and threats in the future is an essential part of the planning process.

Rif'atin emphasized that this tiered plan was carried out to achieve the goals set by the teacher at RA Tania. The final stage in the planning process includes developing alternative activities to accomplish the objectives, the assessment of these alternatives, and selecting the best (most satisfactory) choice among the different options in optimizing program objectives.

Shafiah conveyed the tiered plan chosen by RA Tania, namely literacy management with mobile libraries and nature tourism. These two programs are in a tiered plan because these activities are not routinely carried out but only occasionally in the process of implementation. Thus, it can reinforce or finalize the initial program that is integrated into the tiered program.

Theoretically, it can be understood that the main thing that needs to be done to design a program or training to run effectively is to analyze what is required. Meanwhile, the analysis itself has an element of an investigation into an event (writing, deed, etc.) to find out the actual situation (causes, problems, etc.) (Basri \& Rusdiana, 2015), while the need for discrepancies or gaps between ideal or standard abilities with actual abilities (Deliasari \& Kurnianingsih, 2017).

The identification of needs, according to Warsita (2011) can be interpreted as a description of the current conditions (natural conditions) which are compared with the diseases that should be accompanied by a recommendation of a solution model to overcome the gap between the situation that occurs and the conditions that should happen.

By analyzing all the needs needed in literacy management at RA Tania, all elements that will be implemented for students can be met according to the needs of students. Of course, this can make it easier to manage programs carried out by schools about the development of cognitive abilities in literacy management. Implementation is done by applying a series that is structured and planned in the performance of a program. In delivering or presenting learning to children, it must be engaging, energetic, creative, and innovative so that children are interested in the teaching given by the teacher (Zamroni et al., 2021).

The implementation of literacy management at the RA Tania institution is carried out to develop and improve students' cognitive abilities. RA Tania chose stimulation using literacy management because it was considered capable of realizing and covering the shortcomings of the previous administration. Literacy models are also selected according to procedures and according to the needs of students. 
A tiered plan consists of the following steps that need to be done to improve programs that are already running to get maximum results. This tiered plan can also be called a program evaluation. Evaluation is a process that provides an overview of what is happening in a program and ensures the affordability of the physical and structural elements of the planned schedule. Evaluation is also referred to as the process of obtaining the data and information needed to determine the degree and level of learning that has occurred to make the assessments and improvements required to maximize results.

The evaluation was carried out by all management teams in charge of implementing literacy management in improving early childhood cognitive intelligence. In this process, the management team involved principals, committees, teachers, employees, parents. All teams evaluate deficiencies in the implementation of literacy management at RA Tania and find the best solution using internal meetings by all literacy management teams.

The last step is evaluation. Evaluation is carried out as a follow-up action from monitoring to measure and improve the implemented activities, such as matching the results of activities. The purpose of the evaluation is so that the plans that have been arranged can achieve the goals set and be implemented. The results of the review are intended for replanning and serve as the final administration and management (Baharun \& Wibowo, 2021).

Management of early childhood education at RA Tania becomes critical because the graduates' imagination, creativity, innovation, and proactive power are significantly different from those not through early childhood education. This is important because the global era is full of competition; we need quality human resources with very high competitiveness so that we do not continue to be left behind. For this reason, it is necessary to have qualified human resources to fix and improve the management of early childhood education, specifically related to early childhood education learning, which includes the process of planning, organizing, implementing, and assessing (Ita, 2018).

With a tiered plan carried out in the evaluation of the system, it can provide direction and the next step to optimize the program that is already running. This further strengthens the institution to develop children's cognitive talents through literacy stimuli in schools.

\section{CONCLUSION}

In improving cognitive intelligence in early childhood, careful and planned efforts are needed to achieve development effectively. Literacy management needs to be carried out and designed to meet the elements of problem-solving in early childhood, especially in cognitive intelligence. Literacy management is an alternative solution in improving children's cognitive intelligence at RA Tania. The literacy model in increasing cognitive intelligence in RA Tania can be seen in general terms in the activities of children who begin to develop their cognitive intelligence through writing, reading simple words, and solving problems related to remembering and thinking activities.

\section{Acknowledgement}

Our gratitude goes to the Rector of the University of Nurul Jadid, Paiton, Probolinggo, the Rector of the University of Muhammadiyah Malang, the Rector of UIN Sultan Aji Muhammad Idris Samarinda. They have provided motivation and provided financial assistance to complete this research correctly. Furthermore, the researchers would also like to thank all the leaders and the board of teachers of RA Tania, Paiton, Probolinggo, who have helped researchers complete this research well.

\section{REFERENCES}

Afnida, M., \& Suparno, S. (2020). Literasi dalam Pendidikan Anak Usia Dini: Persepsi dan Praktik Guru di Prasekolah Aceh. Jurnal Obsesi : Jurnal Pendidikan Anak Usia Dini, 4(2), 971. https://doi.org/10.31004/obsesi.v4i2.480 
Alfina, A., \& Anwar, R. N. (2020). Manajemen Sekolah Ramah Anak Paud Inklusi. Al-Tanzim: Jurnal Manajemen Pendidikan Islam, 4(1), 36-47. https://doi.org/10.33650/altanzim.v4i1.975

Anida, A., \& Eliza, D. (2020). Pengembangan Model Pembelajaran Saintifik Berbasis Kearifan Lokal untuk Perkembangan Kognitif Anak Usia 5-6 Tahun. Jurnal Obsesi: Jurnal Pendidikan Anak Usia Dini, 5(2), 1556-1565. https://doi.org/10.31004/obsesi.v5i2.898

Arif, D., \& Pratama, N. (2019). Tantangan Karakter di Era Revolusi Industri dalam Membentuk Kepribadian Muslim. Al-Tanzim: Jurnal Manajemen Pendidikan Islam, 3(1), 198-226. https:// doi.org/10.33650/al-tanzim.v3i1.518

Arimbi, Y. D., Saparahayuningsih, S., \& Ardina, M. (2018). 71 Meningkatkan Perkembangan Kognitif Melalui Kegiatan Mind Mapping. Jurnal Ilmiah Potensia, 3(1), 64.

Baharun, H., \& Wibowo, A. (2021). Kepemimpinan Perempuan dalam Menciptakan Sekolah Ramah Anak. Quality, 9(1), 87-102. https:/ / doi.org/10.21043/quality.v9i1.10109

Basri, H., \& Rusdiana. (2015). Manajemen Pendidikan dan Pelatihan.

Basyiroh, I. (2017). Program Pengembangan Kemampuan Literasi Anak Usia Dini. Tunas Siliwangi, 3(2), 120-134.

Deliasari, A., \& Kurnianingsih, I. (2017). Needs analysis of learning topic on online information literacy in man insan cendekia school library. Edulib, 7(2), 93-107. https:// doi.org/10.17509/edulib.v7i2.9384

Fahmi, F., Syabrina, M., Sulistyowati, S., \& Saudah, S. (2020). Strategi Guru Mengenalkan Konsep Dasar Literasi di PAUD Sebagai Persiapan Masuk SD/MI. Jurnal Obsesi : Jurnal Pendidikan Anak Usia Dini, 5(1), 931-940. https://doi.org/10.31004/obsesi.v5i1.673

Fardiah, F., Murwani, S., \& Dhieni, N. (2019a). Meningkatkan Kemampuan Kognitif Anak Usia Dini melalui Pembelajaran Sains. Jurnal Obsesi : Jurnal Pendidikan Anak Usia Dini, 4(1), 133-'40. https:// doi.org/10.31004/obsesi.v4i1.254

Fardiah, F., Murwani, S., \& Dhieni, N. (2019b). Meningkatkan Kemampuan Kognitif Anak Usia Dini melalui Pembelajaran Sains. Jurnal Obsesi : Jurnal Pendidikan Anak Usia Dini, 4(1), 133. https://doi.org/10.31004/obsesi.v4i1.254

Hayati, I. (2021). Interview. Paiton, Probolinggo.

Heliawati, A. K. R. (2019). Manajemen Pembelajaran Inklusi Pada Anak Usia Dini. Educhild: Jurnal Ilmiah Pendidikan, 3(1), 15-23. https:// doi.org/10.17509/cd.v3i2.10334

Hewi, L. (2020). Pengembangan Literasi Anak Melalui Permainan Dadu Literasi. Thufula, 8(1), 112-124. https://doi.org/10.21043/thufula.v8i1.7238

Ichsan, A., \& Hutagalung, Y. (2019). Manajemen Anak Didik Growing PAUD Inklusi Yogyakarta. Proceedings of The 4th Annual Conference on Islamic Early Childhood Education, 4(1), 327-336.

Inten, D. N., \& Permatasari, A. N. (2019). Literasi Kesehatan pada Anak Usia Dini melalui Kegiatan Eating Clean. Jurnal Obsesi : Jurnal Pendidikan Anak Usia Dini, 3(2), 366. https://doi.org/10.31004/obsesi.v3i2.188

Ita, E. (2018). Manajemen Pembelajaran Pendidikan Anak Usia Dini di TK Rutosoro Kecamatan Golewa Kabupaten Ngada Flores Nusa Tenggara Timur. Jurnal Dimensi Pendidikan Dan Pembelajaran, 6(1), 45-52.

Juniayanti, D., Sedanayasa, G., \& Margunayasa, I. G. (2016). Pengaruh Model Pembelajaran Self Regulated Learning Berbantuan Media Lingkungan terhadap Motivasi Belajar IPA Siswa SD. E-Journal PGSD, 4(1), 1-9.

Made, N., Suryaningsih, A., \& Rimpiati, N. L. (2018). Implementation of Game-Based Thematic Science Approach in Developing Early Childhood Cognitive Capabilities. Jurnal Obsesi : Jurnal Pendidikan Anak Usia Dini, 2(2), 194-201. https://doi.org/10.31004/obsesi.v2i2.90

Mardliyah, S., Siahaan, H., \& Budirahayu, T. (2020). Pengembangan Literasi Dini melalui Kerjasama Keluarga dan Sekolah di Taman Anak Sanggar Anak Alam Yogyakarta. 
DOI: $10.31004 /$ obsesi.v6i3.2022

Jurnal Obsesi : Jurnal Pendidikan Anak Usia Dini, 4(2), 892. https://doi.org/10.31004/obsesi.v4i2.476

Masyithoh, S. (2019). Implementasi Assesmen Perkembangan Kognitif Anak Usia Dini. Jurnal Care Children Advisory Research and Education, 7(1), 27-35.

Mukhibat, M. (2020). Konstruksi Mutu Pendidikan melalui Literasi Keuangan pada Pendidikan Anak Usia Dini di Magetan. Jurnal Obsesi : Jurnal Pendidikan Anak Usia Dini, 4(2), 620. https:// doi.org/10.31004/obsesi.v4i2.412

Mukhtar, N., \& Amalia, R. (2019). Peran Orang Tua dalam Pengenalan Budaya Literasi untuk Meningkatkan Kecerdasan Bahasa Anak Usia Dini 5-6 Tahun di TK Cahaya Bunda Lhokseumawe. Thufula, 7(2), 223-242. https:// doi.org/10.21043/thufula.v7i2.5638

Musaddad, A. (2021). Organizational Culture in the Islamic Boarding School : Phenomenology Review. Al-Tanzim: Jurnal Manajemen Pendidikan Islam, 5(1), 154-164. https://doi.org/10.33650/al-tanzim.v5i1.1982

Nahdi, K., \& Yunitasari, D. (2019). Literasi Berbahasa Indonesia Usia Prasekolah: Ancangan Metode Dia Tampan dalam Membaca Permulaan. Jurnal Obsesi : Jurnal Pendidikan Anak Usia Dini, 4(1), 446. https:// doi.org/10.31004/obsesi.v4i1.372

Nasution, N., Yaswinda, Y., \& Maulana, I. (2019a). Analisis Pembelajaran Berhitung melalui Media Prisma Pintar pada Anak Usia Dini. Jurnal Pendidikan Anak Usia Dini, 4(1), 230-236. https://doi.org/10.31004/obsesi.v4i1.311

Nasution, N., Yaswinda, Y., \& Maulana, I. (2019b). Analisis Pembelajaran Berhitung melalui Media Prisma Pintar pada Anak Usia Dini. Jurnal Obsesi : Jurnal Pendidikan Anak Usia Dini, 4(1), 240. https:// doi.org/10.31004/obsesi.v4i1.311

Ngiode, S., \& Erwinsyah, A. (2020). Keefektifan Program Indonesia Pintar. Al-Tanzim: Jurnal Manajemen Pendidikan Islam, 4(1), 48-58. https://doi.org/10.33650/altanzim.v4i1.987

Novitasari, Y., \& Fauziddin, M. (2020). Perkembangan Kognitif Bidang Auditori pada Anak Usia Dini. Jurnal Obsesi: Jurnal Pendidikan Anak Usia Dini, 5(1), 805-813. https://doi.org/10.31004/obsesi.v5i1.640

Nur, L., Hafina, A., \& Rusmana, N. (2020). Kemampuan Kognitif Anak Usia Dini Dalam Pembelajaran Akuatik. Scholaria: Jurnal Pendidikan Dan Kebudayaan, 10(1), 42-50. https://doi.org/10.24246/j.js.2020.v10.i1.p42-50

Nurmiyanti, L., \& Candra, B. Y. (2019). Kepemimpinan Transformasional dalam Peningkatan Mutu Pendidikan Anak Usia Dini. Al-Tanzim: Jurnal Manajemen Pendidikan Islam, 3(2), 13-24. https://doi.org/10.33650/al-tanzim.v3i2.646

Rahayu, S., Triyanti, S., \& Magdalena, Y. (2014). Pembelajaran di Pendidikan Anak Usia Dini dengan Perkembangan Kognitif pada Anak. Jurnal Kesehatan Masyarakat Nasional, 8(6), 243-249. https:// doi.org/10.21109/kesmas.v0i0.375

Rahmatika, P., Hartati, S., \& Yetti, E. (2019). Metode Pembelajaran Mind Map dan Bercerita dengan Gaya Kognitif, Pengaruhnya terhadap Kemampuan Membaca Permulaan. Jurnal Obsesi: Jurnal Pendidikan Anak Usia Dini, 3(2), 548-560. https://doi.org/10.31004/obsesi.v3i2.260

Rif'atin. (2021). Interview. Paiton Probolinggo.

Ritonga, R. A., \& Sutapa, P. (2020). Literasi dan Gender: Kesenjangan yang Terjadi di Tingkat Pendidikan Anak Usia Dini. Jurnal Obsesi : Jurnal Pendidikan Anak Usia Dini, 5(1), 965-974. https://doi.org/10.31004/obsesi.v5i1.749

Roviin, R. (2020). Manajemen Program Kursus Intensif Bahasa Arab: Studi Pada Metode Mustaqilli. Al-Tanzim: Jurnal Manajemen Pendidikan Islam, 4(2), 118-128. https://doi.org/10.33650/al-tanzim.v4i2.1237

Saefudin, Ahmad, A. W. (2019). Pola Asuh Inklusif Keluarga Seagama dan Beda Agama: Sebuah Model Pendidikan Toleransi Di Desa Bondo Jepara. Jurnal Penelitian Ilmu Sosial Dan Kegamaan Islam, 16(2), 123-137. https://doi.org/10.19105/nuansa.v16i2.2534 
Suryaningrum, C., Ingarianti, T. M., \& Anwar, Z. (2016). Pengembangan Model Deteksi Dini Anak Berkebutuhan Khusus (ABK) Pada Tingkat Pendidikan Anak Usia Dini (PAUD) di Kota Malang. Jurnal Ilmiah Psikologi Terapan, 4(1), 62-74.

Tatminingsih, S. (2019). Alternatif Stimulasi Kemampuan Kognitif melalui Penerapan Model Pembelajaran Berbasis Permainan Komprehensif. Jurnal Obsesi : Jurnal Pendidikan Anak Usia Dini, 3(1), 183-190. https:// doi.org/10.31004/obsesi.v3i1.130

Tharaba, M. F. (2020). Manajemen Pendidikan Multikultural Prespektif Ulu Al-Albab. AlTanzim: Jurnal Manajemen Pendidikan Islam, 4(2), 91-105. https:// doi.org/10.33650/al-tanzim.v4i2.1076

Trenggonowati, D. L., \& Kulsum. (2018). Analisis Faktor Optimalisasi Golden Age Anak Usia. Journal Industrial Servicess, 4(1), 48-56. https://doi.org/10.36055/jiss.v4i1.4088

Wahyono, I. (2019). Mengembangkan Iklim Organisasi di Sekolah dengan Menggunakan Model Tagiuri. Al-Tanzim: Jurnal Manajemen Pendidikan Islam, 3(2), 61-72. https:// doi.org/10.33650/al-tanzim.v3i2.638

Warsita, B. (2011). Pendidikan Jarak Jauh : perancangan, pengembangan, implementasi, dan evaluasi diklat.

Yarmi, G., \& Wardhani, P. A. (2020). Efektivitas Pengembangan Karakter melalui Fun Garden of Literacy Bagi Anak Usia 7 Tahun. Jurnal Obsesi : Jurnal Pendidikan Anak Usia Dini, 4(2), 1068. https://doi.org/10.31004/obsesi.v4i2.492

Yuwono, W. (2020). Konseptualisasi Peran Strategis dalam Pendidikan Literasi Keuangan Anak melalui Pendekatan Systematic Review. Jurnal Obsesi : Jurnal Pendidikan Anak Usia Dini, 5(2), 1419-1429. https:// doi.org/10.31004/obsesi.v5i2.663

Zamroni, Amir, \& Saleha, L. (2021). Pengelolaan APE Berbahan Limbah untuk Meningkatkan Kecerdasan Kognitif Anak. Jurnal Obsesi: Jurnal Pendidikan Anak Usia Dini, 5(2), 1382-1395. https://doi.org/10.31004/obsesi.v5i2.763

ZR, Z., \& Eliza, D. (2020). Pengembangan Science Book Anak untuk Pengenalan Literasi dan Karakter Berbasis Budaya Alam Minangkabau. Jurnal Obsesi : Jurnal Pendidikan Anak Usia Dini, 5(2), 1567-1577. https://doi.org/10.31004/obsesi.v5i2.896 